\section{Immersion Immunization of Ayu (Plecoglossus altivelis) with Pseudomonas plecoglossicida Bacterin}

\section{Sukenda* and Hisatsugu Wakabayashi}

Department of Aquatic Bioscience, Graduate School of Agricultural and Life Sciences, The University of Tokyo, Yayoi 1-1-1, Bunkyo-ku, Tokyo 113-8657, Japan

(Received August 21, 1998)

\begin{abstract}
Key words: Pseudomonas plecoglossicida, immunization, bacterial hemorrhagic ascites, ayu
\end{abstract}

Bacterial hemorrhagic ascites ( $\mathrm{BHA}$ ) of ayu has been reported as a new disease causing mass mortality among cultured ayu (Plecoglossus altivelis) ${ }^{1)}$. The causative agent of the disease was recently given the name Pseudomonas plecoglossicida ${ }^{2)}$. The disease is characterized by bloody ascites with a large number of bacteria in the blood and internal organs of affected fish.

As $P$. plecoglossicida is resistant to medicines licenced for cultured ayu, the development of a protective vaccine is a possible method for the control of BHA. In the present study, immersion immunization of ayu with formalin-killed $P$. plecoglossicida bacterin was evaluated by challenge test. The kinetics of invading $P$. plecoglossicida in the organs of immunized fish was also investigated.

\section{Materials and Methods}

Ayu weighing about $7 \mathrm{~g}$ were obtained from Yamanashi Prefectural Fisheries Technology Center and maintained at about $23^{\circ} \mathrm{C}$ at the Fisheries Laboratory of the University of Tokyo from July to September 1997.

$P$. plecoglossicida strain FPC 941 was isolated from an ayu during an outbreak of $\mathrm{BHA}$ at Shiga Prefecture in 1994. The strain was kept frozen at $-80^{\circ} \mathrm{C}$ in tryptic soy broth (Nissui) containing 10\% (v/v) glycerol.

The bacterin, composed of formalin-killed cells of $P$. plecoglossicida strain FPC 941, was provided by Kyouritsu Shouji Co. Ltd., Tokyo at a concentration of $1.7 \times 10^{10} \mathrm{CFU} / \mathrm{mL}$. The vaccine was diluted 1:100 in dechlorinated water shortly before use. Three hundred fish were taken from the stock, and divided into experimental and control groups. The experimental fish were immersed in $40 \mathrm{~L}$ of the vaccine solution for 30 min with aeration. Control fish were immersed in dechlorinated

\footnotetext{
* Corresponding author

E-mail: aa87078@hongo. ecc.u-tokyo.ac.jp
}

water for $30 \mathrm{~min}$. Two weeks after immunization, the experimental fish were divided into two groups, one of which was given a booster immersion. The booster was performed for $20 \mathrm{~min}$ in the same manner as the initial immunization. Water temperature during the experiment was about $23^{\circ} \mathrm{C}$.

Immunized and control fish were challenged with $P$. plecoglossicida by immersion in $3 \times 10^{7} \mathrm{CFU} / \mathrm{mL}$ for 15 min at either 2, 4 or $6 \mathrm{wk}$ after the initial immunization. Ten fish were transferred to a $30 \mathrm{~L}$ container with flowing water for observation of mortality, and the remaining fish were transferred to another container for observation of the fate of challenging bacteria in the liver, spleen, kidney and blood of the fish. Mortalities were recorded for 10 days post-challenge, and the efficacy of vaccination was evaluated as relative percent survival (RPS) ${ }^{3)}$.

Three fish were taken from each group, 1, 2 and 3 days after challenge with the bacteria. Fish were anesthetized with 250 ppm of 2-phenoxyethanol and then bled from the caudal vein with a heparinized syringe. The liver, spleen and kidney samples were separately homogenized $(10 \% \mathrm{w} / \mathrm{w})$ in sterile physiological saline. The blood and homogenates were serially diluted 10-fold with physiological saline. Duplicates of $25 \mu \mathrm{L}$ of each diluted solution were plated on tryptic soy agar (Nissui). After $24 \mathrm{~h}$ of incubation at $25^{\circ} \mathrm{C}$, bacterial colonies were counted, and colony forming units (CFU) per $\mathrm{g}$ of tissue or $\mathrm{mL}$ of blood was determined.

Data of mortalities were analyzed by Fisher's exact probability test. Differences were considered significant at $P<0.05$.

\section{Results and Discussion}

In challenge tests with $P$. plecoglossicida, the immunized fish had lower mortalities than the controls (Table 1). Three days after challenge, both immunized and control fish began dying, and a symptom of BHA, bloody ascites, appeared in the dead fish. The mortalities continued for $1 \mathrm{wk}$. The results indicate that immersion immunization induces protective immunity against BHA in ayu. In addition, it is concluded that a booster immunization is effective in keeping protective immunity longer.

The fate of invading $P$. plecoglossicida in the organs of ayu 6 wk after immunization is shown in Table 2 . In fish immunized twice, the bacterium was not detected at 1,2 and 3 days post-challenge. A high level of protection against $P$. plecoglossicida infection was seen in this group. However, in the fish immunized once, the bacterium was detected in one of three fish at 1,2 and 3 days post-challenge. We suppose that some fish did not have sufficient protective immunity. In the control fish, the bacterium was detected at 1 day post-challenge, and increased in number toward 2 and 3 days postchallenge. Similar results were obtained in the chal- 
Table 1. Duration of protection : mortalities of immunized and unimmunized control ayu 2,4 , and 6 wk after initial immunization with a Pseudomonas plecoglossicid bacterin

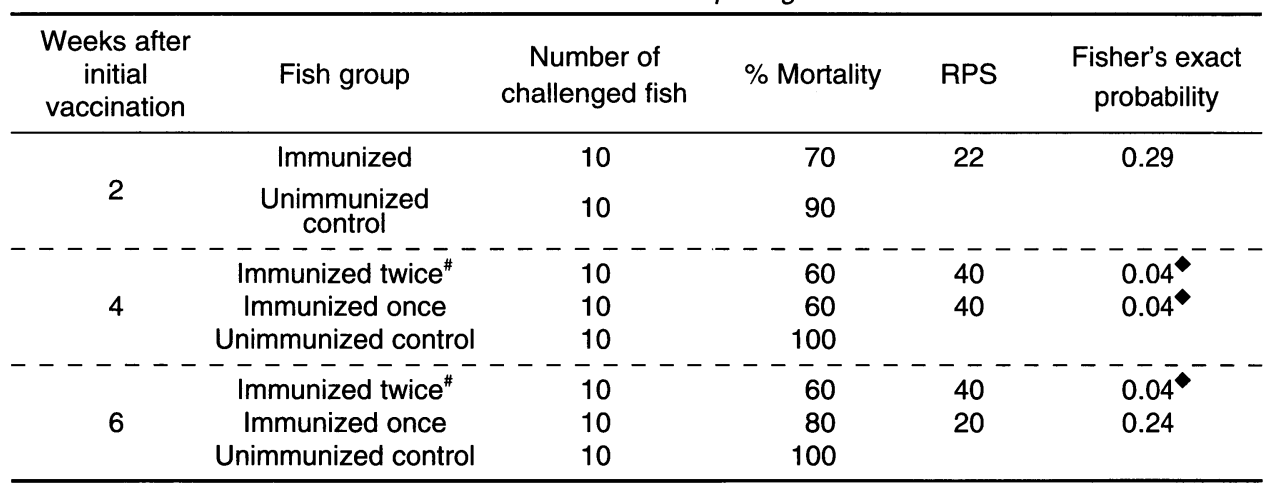

\# : Booster was administred 2 wk after the initial immunization.

: Significantly different when compared with unimmunized control $(P<0.05)$

Table 2. Distribution of Pseudomonas plecoglossicida in ayu challenged by immersion at a concentration of $3 \times 10^{7} \mathrm{CFU} / \mathrm{mL} 6$ wk after initial immunization

\begin{tabular}{|c|c|c|c|c|c|}
\hline \multirow{2}{*}{$\begin{array}{l}\text { Days after } \\
\text { challenge }\end{array}$} & \multirow{2}{*}{ Group } & \multicolumn{4}{|c|}{ P. plecoglossicida in (CFU/g or $\mathrm{mL}$ ) } \\
\hline & & Liver & Spleen & Kidney & Blood \\
\hline 1 & $\begin{array}{c}\text { Immujnized } \\
\text { twice } \\
\text { Immunized } \\
\text { once } \\
\text { Unimmunized } \\
\text { control }\end{array}$ & $\begin{array}{c}- \\
- \\
- \\
---- \\
- \\
- \\
1.2 \times 10^{3} \\
---- \\
- \\
- \\
-\end{array}$ & $\begin{array}{c}- \\
- \\
- \\
----- \\
- \\
- \\
- \\
---- \\
- \\
- \\
-\end{array}$ & $\begin{array}{c}- \\
- \\
- \\
----- \\
- \\
- \\
2.5 \times 10^{3} \\
----- \\
- \\
4.6 \times 10^{3} \\
8.0 \times 10^{3}\end{array}$ & $\begin{array}{c}- \\
- \\
- \\
----- \\
- \\
- \\
- \\
---- \\
- \\
- \\
-\end{array}$ \\
\hline 2 & $\begin{array}{c}\text { Immunized } \\
\text { twice } \\
\text { Immunized } \\
\text { once } \\
\text { Unimmunized } \\
\text { control }\end{array}$ & $\begin{array}{c}- \\
- \\
- \\
---- \\
- \\
- \\
- \\
-\overline{-}-- \\
- \\
- \\
-\end{array}$ & $\begin{array}{c}- \\
- \\
- \\
--- \\
- \\
- \\
2.7 \times 10^{5} \\
---- \\
- \\
- \\
9.0 \times 10^{3}\end{array}$ & $\begin{array}{c}- \\
- \\
- \\
----- \\
- \\
- \\
1.0 \times 10^{4} \\
----- \\
- \\
8.0 \times 10^{2} \\
8.8 \times 10^{3}\end{array}$ & $\begin{array}{c}- \\
- \\
- \\
----- \\
- \\
- \\
4.0 \times 10^{2} \\
----- \\
- \\
- \\
-\end{array}$ \\
\hline 3 & $\begin{array}{c}\text { Immunized } \\
\text { twice } \\
\text { Immunized } \\
\text { once } \\
\text { Unimmunized } \\
\text { control }\end{array}$ & $\begin{array}{c}- \\
- \\
- \\
-\overline{-}-- \\
- \\
1.3 \times 10^{6} \\
-\overline{-}-\overline{10} \\
2.0 \times 10^{3} \\
2.0 \times 10^{4} \\
2.4 \times 10^{4}\end{array}$ & $\begin{array}{c}- \\
- \\
- \\
--- \\
- \\
- \\
1.0 \times 10^{8} \\
\overline{9} .0 \times 10^{4} \\
1.0 \times 10^{5} \\
2.3 \times 10^{5}\end{array}$ & $\begin{array}{c}- \\
- \\
- \\
--- \\
- \\
- \\
7.4 \times 10^{6} \\
\overline{9} \overline{-}-\overline{1} 0^{3} \\
4.3 \times 10^{3} \\
5.4 \times 10^{4}\end{array}$ & $\begin{array}{c}- \\
- \\
- \\
----- \\
- \\
- \\
8.0 \times 10^{5} \\
----- \\
- \\
2.6 \times 10^{2}\end{array}$ \\
\hline
\end{tabular}

lenge tests 2 and 4 wk after the initial immunization (data not shown). The high CFU level of $P$. plecoglossicida in control fish 3 days after challenge indicates a rapid proliferation of the bacteria in fish succumbing to infection.

\section{References}

1) Wakabayashi, H., K. Sawada, K. Ninomiya and E. Nishimori (1996): Fish Pathol 31, 239-240. 2) Nishimori, E., K. KitaTsukamoto and H. Wakabayashi (1999): Int. J. Syst. Bacteriol. (in press). 3) Ellis, A. E. (1988): Fish Vaccination. Academic Press, London, pp. 1-19. 